\title{
MENCIPTAKAN GENERASI LITERAT MELALUI MEDIA MASSA SURAT
}

\author{
Ima Siti Rahmawati \\ Universitas Majalengka \\ Pos-el: rahma_ima89@yahoo.co.id
}

\begin{abstract}
ABSTRAK
"Bangsa yang berbudaya ialah bangsa yang membiasakan budaya literasi (melekwacana) bukan sekadar budaya orasi (berbicara). Pada hakikatnya penyebaran budaya literasi meliputi budaya baca dan tulis. Sedangkan budaya orasi meliputi kebudayaan masyarakat dalam bertutur kata, dan menerima informasi. Dalam konteks keterampilan berbahasa bahwa literasi secara sederhana diartikan sebagai kemampuan membaca dan menulis. Seseorang dikatakan literat apabila bisa memahami sesuatu karena membaca informasi yang tepat dan melakukan sesuatu berdasarkan pemahaman terhadap isi bacaan tersebut. Surat kabar merupakan salah satu media massa turut berperan dalam mempublikasikan budaya literasi hadir di masyarakat. Melalui surat kabar, gagasan yang disampaikan mengenai persoalan yang hangat dibicarakan di tengah masyarakat dapat dipahami lebih luas. Kehadirannya membuat masyarakat menjadi kritis, peka terhadap informasi, dan mampu meningkatkan kualitas dan kuantitas intlektual. Selain itu, media massa surat kabar mampu membentuk kebiasaan berliterasi dimulai dari kebiasaan berpikir dari pemahaman isu/persoalan yang diikuti oleh sebuah proses membaca, kemudian menulis yang pada akhirnya akan menciptakan karya. Literasi juga erat kaitannya dengan pola pembelajaran di sekolah yaitu ketersediaan bahan bacaan dan tumbuhnya masyarakat gemar membaca (reading society). Dengan demikian, budaya literasi sebagai pembentuk generasi literat bisa dikatakan sebagai akar dari peradaban yang mampu mentransformasi pola pikir dan perilaku.
\end{abstract}

Kata Kunci : Generasi Literasi, Media Massa, Surat Kabar. 


\section{PENDAHULUAN}

Dewasa ini seluruh negara gencar meningkatkan insan yang literat, hal ini tentu saja dipengaruhi oleh kemajuan zaman serta peradaban yang semakin membuat manusia terus berkembang untuk memenuhi kebutuhan hidupnya, serta dapat mengaktualisasikan dirinya.

Oleh karena itu, abad ke-21 disebut sebagai era globalisasi yang ditandai dengan semakin bersatunya dunia baik secara fisik maupun emosional. Dunia menjadi tanpa batas, teknologi informasi dan komunikasi dapat diakses secara mudah hanya dalam beberapa detik saja,hal ini menjadikan semua negara di dunia dapat terhubung satu sama lain tanpa adanya batasan. Batas-batas fisik suatu negara dan batas administrasi pemerintahan seolah-olah menjadi tidak berarti lagi. Semua orang di dunia dapat dengan mudah melakukan pekerjaan karena dibantu dengan adanya "mesin", tentu saja mensin merupakan hasil dari teknologi seperti halnya komputer yang digunakan untuk memudahkan manusia dalam melakukan pengadministrasian pendidikan, masyarakat, perkantoran dan lain sebagainya. Kemudian, komunikasi lebih mudah dan tentu saja dapat dilakukan kapanpun, dimanapun, hal tersebut tentu saja merupakan hasil dari semakin majunya teknologi yang diciptakan manusia. Semua informasi dapat diakses dengan mudah hanya dengan gawai. Perjalanan yang biasanya ditempuh berjam-jam kini hanya beberapa menit saja, tentu saja teknologi yang semakin maju karena kualitas manusia juga semakin meningkat.

Oleh sebab itu, maka semua pihak perlu menyiapkan diri secara proaktif serta lebih berkeinginan untuk mengaktualisasikan diri dengan budaya literasi bukan hanya orasi. Namun, ada berbagai hal yang perlu diperhatikan, misalnya mengenai revolusi industri baru, bioteknologi serta pemantapan dibidang literasi. Akan semakin penting jika dihubungkan dalam konteks Pembangunan Nasional Indonesia. Tentu saja, pembangunan suatu negara tidak akan pernah terlepas dari peranan media massa dikarenakan media massa berperan sebagai agen pembangunan memiliki peran yang penting dan signifikan dalam rangka pembangunan nasional. Media massa-surat kabar, majalah, radio, media sosial dan televisi semakin banyak dijadikan sebagai objek studi. Dengan meningkatnya peran media massa sebagai suatu institusi penting dalam masyarakat. Surat kabar tidak hanya sekadar berperan sebagai sumber informasi tetapi juga telah 
FON ; Jurnal Pendidikan Bahasa dan Sastra Indonesia Volume 13 Nomor 2 Tahun 2018

menjadi lembaga sosial yang melakukan kontrol sosial, kontrol budaya dan literasi terhadap jalannya pemerintahan dan pembangunan Nasional. Namun seiring dengan makin berkembangnya teknologi, khususnya teknologi informasi maka lewat internet dapat diperoleh berbagai informasi yang dapat diakses semua pihak tanpa terkecuali. Surat kabar berubah wujud, bukan lagi sebagai media cetak tetapi juga telah menjadi surat kabar elektronik, hal ini tentu saja karena bergesernya kebiasaan masyarakat yang beralih pada media elektronik dibandingkan dengan media cetak. Di sisi lain bermunculannya media sosial seperti facebook, twiter, path, instagram dan lainlain memberikan banyak alternatif bagi masyarakat untuk memperoleh informasi tidak hanya lewat media massa konvensional seperti surat kabar, majalah, , radio dan televisi. Selain itu, sekarang telah tersedia majalah digital, radio internet dan televisi internet. Semua itu tentunya membawa pengaruh terhadap kegiatan literasi masyarakat. Salah satu faktor penting dalam pembangunan adalah sumber daya manusia yang berkualitas. Ini dapat dicapai dengan pendidikan yang baik. Untuk itu maka generasi muda saat ini harus mampu mengambil kesempatan dalam kerangka menjadi manusia yang intelek dan berkepribadian serta mampu menjadi pemimpin nasional di masa depan. Salah satu aspek penting dalam kerangka peningkatan kualitas pendidikan adalah dengan mendorong generasi muda untuk memiliki minat baca yang tinggi agar mampu lebih menyerap berbagai informasi dan ilmu pengetahuan. Bertitik tolak dari latar belakang masalah maka dapat ditentukan rumusan masalahnya, yaitu: Bagaimanakah literasi media masa ? Serta bagaimanakah generasi literat pada saat ini?.

\section{PEMBAHASAN}

\section{GENERASI LITERAT}

Menurut Fahrudin (2017: 1) generasi literat hakikatnya ialah generasi yang memiliki jiwa literasi. Literasi berarti pemahaman, penyadaran, dan pemaknaan. Hal ini berlaku untuk semua hal, termasuk dalam dunia pendidikan. Dunia pendidikan Indonesia perlu generasi yang literat agar pendidikan di negeri ini bisa bangkit dari keterpurukan. Dengan kata lain, menciptakan generasi literat merupakan jembatan awal menuju bangsa yang makmur, peduli, dan kritis. Oleh sebab itu, pengenalan budaya literasi kepada ge-nerasi muda harus ditanamkan sejak dini baik di lingkungan keluarga, sekolah, maupun masyarakat. Gerakan 
FON ; Jurnal Pendidikan Bahasa dan Sastra Indonesia

Volume 13 Nomor 2 Tahun 2018

semangat membaca-menulis harus pengetahuan yang dicapainya dengan ditransformasikan ke ruang pendidikan membaca, menulis, dan arithmetic kita. Gerakan ini mewajibkan seluruh memungkinkan untuk dimanfaatkan bagi elemen pendidikan negeri ini, bahkan jika dirinya sendiri dan perkembangan perlu sistem pendidikan negeri ini perlu direformasi agar mampu mengembangkan kemampuan berliterasi sejak usia dini.

Secara singkat dapat masyarakat.

Kemudian literasi dapat diartikan kemampuan seseorang dalam mengolah dan memahami informasi saat melakukan disimpulkan bahwa generasi literat adalah generasi yang senantiasa membudayakan membaca dan menulis. Budaya membaca dan menulis lebih dikenal dengan Literasi gerakan literasi ini bukan hanya dalam segi wawasan kognitif, tetapi lebih mencakup pada penguasaan berbagai informasi serta mampu mengolah informasi dan mengomunikasikannya. Literasi tidak hanya mencakup media nonelektronik seperti buku, kemajuan zaman saat ini menuntut generasi muda untuk melek teknologi serta memanfaatkannya dengan bijak demi kemajuan bangsa.

\section{LITERASI}

Menurut Teale dan Sulzby dalam Gipayana (2010:9) konsep pengajaran literasi diartikan sebagai kemampuan membaca dan menulis. Seseorang disebut literate apabila ia memiliki pengetahuan yang hakiki untuk digunakan dalam setiap aktivitas yang menuntut fungsi literasi secara efektif dalam masyarakat dan proses membaca dan menulis. Literasi memerlukan serangkaian kemampuan kognitif, pengetahuan bahasa tulis dan lisan, pengetahuan tentang genre dan kultural. Literasi juga erat kaitannya dengan pola pembelajaran di sekolah yaitu ketersediaan bahan bacaan dan tumbuhnya masyarakat gemar membaca (reading society). Dengan demikian, budaya literasi sebagai pembentuk generasi literat bisa dikatakan sebagai akar dari peradaban yang mampu mentransformasi pola pikir dan perilaku.Kaitan antara literasi dan kemajuan generasi jelas sangatlah erat karena budaya literasi yang sudah melekat akan menjadikan bangsa lebih kritis, lebih kaya akan wawasan, informasi dan tentunya akan melahirkan berbagai gagasan,konsep serta mampu berkomunikasi secara efektif dan tentunya memiliki pemikiran luas dan cerdas.

Jadi, keberaksaraan atau literasi dapat diartikan melek teknologi, melek informasi, berpikir kritis, peka terhadap 
FON ; Jurnal Pendidikan Bahasa dan Sastra Indonesia Volume 13 Nomor 2 Tahun 2018

lingkungan, bahkan juga peka terhadap politik. Seorang dikatakan literat jika ia sudah bisa memahami sesuatu karena membaca informasi yang tepat dan melakukan sesuatu berdasarkan pemahamannya terhadap isi bacaan tersebut. Kepekaan atau literasi pada seseorang tentu tidak muncul begitu saja. Tidak ada manusia yang sudah literat sejak lahir. Menciptakan generasi literat membutuhkan proses panjang dan sarana yang kondusif. Proses ini dimulai dari kecil dan dari lingkungan keluarga, lalu didukung atau dikembangkan di sekolah, lingkungan pergaulan, dan lingkungan pekerjaan. Budaya literasi juga sangat terkait dengan pola pemelajaran di sekolah dan ketersediaan bahan bacaan di perpustakaan. Tapi kita juga menyadari bahwa literasi tidak harus diperoleh dari bangku sekolah atau pendidikan yang tinggi. Kemampuan akademis yang tinggi tidak menjamin seseorang akan literat. Pada dasarnya kepekaan dan daya kritis akan lingkungan sekitar lebih diutamakan sebagai jembatan menuju generasi literat, yakni generasi yang memiliki ketrampilan berpikir kritis terhadap segala informasi untuk mencegah reaksi yang bersifat emosional.

\section{MEDIA MASSA}

Media massa adalah istilah untuk menggambarkan bentuk komunikasi yang dilakukan lewat media massa untuk umum. Media massa yang dikategorikan sebagai alat, instrument komunikasi yang memungkinkan kita untuk merekam serta mengirim intormasi dan pengalamanpengalaman dengan cepat kepada khalayak luas, terpencar-pencar dan heterpgen. Media massa diartikan sebagai alat, instrumen komunikasi yang memungkinkan seseorang untuk merekam serta mengirim informasi dan pengalaman-pengalaman dengan cepat kepada khalayak yang luas, terpencarpencar dan heterogen (Achmad, 1992: 10).

Sehingga dapat disimpulkan bahwa media massa adalah suatu alat, isntrumen guna menuliskan serta menyampaikan informasi kepada khalayak umum dan salah satu sarana bagi warga negara untuk mengeluarkan pikiran dan pendapat serta memiliki peranan penting dalam negara demokrasi. Media massa terdiri dari beragam jenis diantaranya ialah surat kabar.

Surat kabar merupakan salah satu ragam dari ruang lingkup jurnalisme cetak. Surat kabar adalah lembaran tercetak yang memuat laporan yang terjadi 
FON ; Jurnal Pendidikan Bahasa dan Sastra Indonesia

Volume 13 Nomor 2 Tahun 2018

di masyarakat dengan ciri-ciri terbit secara periodik, bersifat umum, isinya termasa dan aktual mengenai apa saja dan dimana saja di seluruh dunia untuk diketahui pembaca (Effendy,2008: 241). Surat kabar dikembangkan untuk bidang-bidang tertentu, misalnya berita untuk industri tertentu, penggemar olahraga tertentu, penggemar seni atau partisipan kegiatan tertentu. Jenis surat kabar umum biasanya diterbitkan setiap hari, kecuali pada harihari libur. Surat kabar sore juga umum di beberapa negara. Selain itu, juga terdapat surat kabar mingguan yang biasanya lebih kecil dan kurang prestisius dibandingkan dengan surat kabar harian dan isinya biasanya lebih bersifat hiburan. Surat kabar atau koran adalah barang cetakan yang berisi berita, informasi dan pendidikan yang terbit secara kontiniu yang biasanya harian. Surat kabar merupakan salah satu bentuk media cetak yang tidak dijilid, dalam ukuran normal dan tiap halaman terdiri 9 kolom. Ada yang terbit 8 halaman, 12 halaman, 16 halaman dan ada yang lebih dari jumlah itu.

\section{LITERASI MEDIA MASSA}

Literasi dan media massa merupakan dua hal yang tidak dapat dipisahkan apalagi di era digital seperti sekarang. Di era digital manusia tidak akan mau tertinggal dalam hal informasi dan komunikasi, tentu saja hal ini dikarenakan perkembangan zaman dan kebutuhan aktualisasi diri manusia yang meningkat. Maka dari itu, seperti yang sudah dipaparkan sebelumnya bahwa generasi literat haruslah tercipta karena dengan budaya literasi maka kualitas generasi bangsa akan terus meningkat. Kemudian di masyarakat dapat disaksikan bahwa teknologi komunikasi terutama televisi, komputer, dan internet telah mengambil alih beberapa fungsi sosial manusia (masyarakat). Setiap saat kita semua menyaksikan realitas baru di masyarakat, dimana realitas itu tidak sekedar sebuah ruang yang merefleksikan kehidupan masyarakat nyata dan peta analog atau simulasi-simulasi dari suatu masyarakat tertentu yang hidup dalam media dan alam pikiran manusia, akan tetapi sebuah ruang di mana manusia bisa hidup di dalamnya. Media massa merupakan salah satu kekuatan yang sangat mempengaruhi umat manusia di abad 21. Media ada di sekeliling kita, media mendominasi kehidupan kita dan bahkan mempengaruhi emosi serta pertimbangan kita.

Literasi media massa memiliki tujuan dasar yaitu memberikan edukasi 
pada khalayak dan pengguna media untuk menganalisis pesan yang disampaikan oleh media massa, mempertimbangkan tujuan komersil dan politik di balik suatu citra atau pesan media, dan meneliti siapa yang bertanggungjawab atas pesan atau gagasan yang diimplikasikan oleh pesan atau citra itu. Seseorang pengguna media yang mempunyai literasi media atau melek media akan berupaya memberi reaksi dan menilai sesuatu pesan media dengan penuh kesadaran dan tanggung jawab. Kajian literasi media menyediakan pengetahuan, informasi, dan statistik tentang media dan budaya, serta memberi pengguna media dengan satu set peralatan untuk berfikir dengan kritis terhadap idea, produk atau citra yang disampaikan dan dijual oleh isi media massa.

Sekarang ini, eksploitasi pers dan media interaktif telah menuju ke arah penciptaan supremasi media yang mengancam keberadaan cara pandang objektif dan ruang publik. Hal ini sesuai dengan pandangan teori hegemoni; peran media bukan lagi sebagai pengawas (watchdog) pemerintah, tetapi justru menopang keberadaan kaum kapitalis dengan menyebarkan pemikiranpemikiran mereka. Kemudian, literasi media massa memang haruslah tercipta dan terus ditingkatkan karena sekarang banyak sekali beredar mengenai berita palsu atau yang lebih dikenal dengan hoax. Tanpa adanya literasi media massa maka seseorang akan dengan mudah menerima begitu saja suatu berita tanpa berpikir kritis mengenai kebenaran berita tersebut. Hal ini tentu saja akan sangat berbahaya karena dapat memprovokasi dan memecah belah kesatuan bangsa.

Secara sederhana, media literasi pada dasarnya merupakan kepedulian masyarakat terhadap dampak buruk dari media, khususnya media massa. Perkembangan teknologi komunikasi, khususnya berkenaan dengan keberadaan media massa, di samping memberikan manfaat untuk kehidupan manusia ternyata juga memberikan dampak lain yang kurang baik. Beberapa dampak tersebut antara lain (1) Mengurangi tingkat privasi individu, (2) Meningkatkan potensi kriminal, (3) Anggota suatu komunitas akan sulit dibatasi mengenai apa yang dilihat dan didengarnya, (4) internet akan mempengaruhi masyarakat madani dan kohesi sosial, serta (5) Akan overload-nya informasi (Fukuyama dan Wagner, 2000).

Dalam upaya menyikapi pengaruh media massa seperti itu, saat ini berkembang pemikiran tentang media literasi. Media literasi merupakan gerakan 
FON ; Jurnal Pendidikan Bahasa dan Sastra Indonesia

Volume 13 Nomor 2 Tahun 2018

penting dalam rangka mengendalikan

Langkah pemerintah untuk kepentingan dan pengaruh media massa peningkatan generasi literasi saat ini dalam pendidikan, kehidupan individu, keluarga dan masyarakat serta membantu kita merancang tindakan dalam menangani pengaruh tersebut. Dalam kata lain, literasi media ini membantu individu menjadi melek media.

\section{GENERASI LITERASI SAAT INI}

Generasi literasi saat ini memang belum mencapai tujuan yang diharapkan seperti yang diungkapkan oleh Balitbang Kemendikbud Toto Supriyatno dalam Temu INOVASI pada 26 Juli 2018 yang dimuat dalam Kompas edisi 26/07/2018 mengemukakan bahwa budaya membaca dan literasi masyarakat Indonesia masih tergolong rendah, jika dalam literasi membaca dan menulis saja masih rendah, bagaimana dengan literasi dalam penguasaan teknologi informasi dan komunikasi. Namun, berbagai upaya coba dilakukan oleh pemerintah guna meningkatkan generasi literasi salah satunya ialah Gerakan Literasi Nasional, Gerakan Literasi Sekolah dan program lainnya yang diselenggarakan oleh Badan Pengembangan dan Pembinaan Bahasa (Badan Bahasa) dan Kemendikbud dengan tujuan meningkatkan budaya literasi saat ini. 
FON ; Jurnal Pendidikan Bahasa dan Sastra Indonesia

Volume 13 Nomor 2 Tahun 2018

berupaya guna menciptakan

SARAN

generasi literasi yang lebih baik.

Menciptakan generasi literasi memerlukan berbagai dukungan dari

\section{SIMPULAN DAN SARAN}

Literasi masyarakat Indonesia masih tergolong rendah. Namun permasalahan ini dapat diatasi dengan berbagai dukungan dari banyak pihak. Generasi literasi atau generasi yang melek terhadap informasi dan komunikasi tidak dapat diciptakan secara instan, tetapi melalui berbagai proses serta tahapan. Upaya peningkatan generasi literasi yang dilakukan oleh pemerintah hendaknya diusahakan pula oleh masyarakat serta lingkungan keluarga dengan pemanfaatan media massa sebagai sarana guna meningkatkan generasi literasi. Generasi literasi yang matang akan mampu mengolah berbagai informasi serta mengkomunikasikannya secara tepat dan tentu saja semakin meningkatnya literasi maka akan meningkat pula wawasan dan pemikiran manusia mengenai berbagai aspek kehidupan serta dapat mengaktualisasikan dirinya berdasarkan kemampuan dan keterampilan yang telah dimiliki. berbagai pihak maka dari itu, hendaknya kita mampu memberikan sumbangsih yang nyata baik itu sumbangsih terhadap penerapan budaya literasi kepada diri sendiri atau menciptakan generasi literasi di lingkungan rumah, masyarakat maupun di lingkungan kelas, universitas dan lain sebagainya.

\section{DAFTAR PUSTAKA}

Apriadi Tamburaka. 2013. Literasi Media: Cerdas bermedia khalayak media massa. Jakarta: Rajawali Pers.

Diterjemahkan oleh Setiawan Abadi:’Media, Komunikasi, Kebudayaan: Suatu Pendekatan Global'. Cetakan I; Jakarta: Yayasan Obor Indonesia.

Gipayana Muhana. 2010. Pengajaran Literasi. Malang: Penerbit A3.

Haris Fahrudin Haris. "Ciptakan Generasi Literat Antiplagiat”. 09 Oktober 2018.

Liliweri, Alo. 1991. Komunikasi Massa Dalam Masyarakat. Cetakan 1. Bandung; P.T . CITRA ADITYA BAKTI.

Lull, James. 1998. Media, Communication and Culture: A Global Approach. Marsel Ruben payong, ”Media 
FON ; Jurnal Pendidikan Bahasa dan Sastra Indonesia

Volume 13 Nomor 2 Tahun 2018

Literacy, Agenda Pendidikan yang Onong Uchjana Effendy. 2008.

Terlupakan”,

Dinamika komunikasi. Bandung: Remaja

Rivers, William L. 2008. Media Rosdakarya.

massa dan masyarakat moderen. Cetakan

3; Jakarta; Prenada Media Grup. 